\title{
A preliminary study on the training mode of tourism talents under the thought of supply-side reform
}

\author{
Yun Sun Qian Liu \\ (China Institute of labor relations, Beijing, China)
}

\begin{abstract}
In our country, the reform of the "supply side" the big strategy under the background of the rapid development of tourism in the cultivation of how to better match the market demand of tourism practitioners is the industry needs to solve the hot issues of concern, and tourism management in colleges and universities in the aspect of tourism management professional talent training plays a very important role. In terms of talent training in tourism management colleges and universities, due to the differences in the development of tourism, social culture and teaching methods and curriculum Settings of colleges and universities, foreign tourism education started earlier in the training mode of tourism talents, with certain advantages, and many domestic tourism management colleges and universities have done very well. After continuous exploration in tourism education, the school of hotel management in lausanne, Switzerland has developed a relatively perfect and unique training mode for tourism talents. And our country to Beijing second foreign languages institute of hotel management college of tourism management college have a certain college characteristics and the characteristics of tourism management education in China, this article selects two schools as sample, the personnel training mode, this paper tries to find talent training mode of China's tourism management colleges can draw lessons from of place, in order to promote the progress of our country's tourism management talents training mode, thus promote the development of tourism in our country, calls supply side reform strategy, improve the level of economy in our country.
\end{abstract}

Keywords: Supply-side Structural Reform, tourism management, personnel training

About the author: Sun Yun, female, born in April 1974 in Jinan, Shandong Province. Now he is a teacher and senior economist of Hotel Management College of China Institute of labor relations.

DOI: $10.36012 /$ fhe.v2i1.1566

\section{Research background}

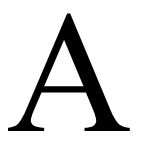

t the eleventh meeting in 2015, General Secretary Xi Jinping first proposed the strategy of "supply-side structural reform", emphasized on improving the quality of the supply side as the starting point, innovated with reform, and promoted the continuous adjustment and optimization of the industrial structure to realize the improvement of people's living standards and the sustainable development of economy finally. The rapid development of China's economy has made people spend more on travel so that the tourism industry's stimulus to China's economic development is becoming increasingly obvious. ${ }^{[1]}$ Therefore, improving the quality of the tourism supply side is actually one of the important ways to promote the development of China's economic supply side.

Under this important background, optimizing the talent training model in tourism education to cultivate high-quality talents that meet the needs of the industry will become one of the important factors that promote the rapid development of China's tourism industry, and at the same time, it will also become one of the key forces to help the development of China's tourism industry. As an important source of supply for tourism management professionals in China, tourism management schools shall think deeply and practice actively to discuss how to cultivate more outstanding tourism management professionals. In order to cultivate tourism management professionals more suitable for this industry in the context of supply-side reform, it is necessary to realize efficient professional training planning. While providing high-quality talents for the tourism industry, tourism management schools can also play their due contributions in the supply-side reform strategy. ${ }^{[2]}$

This paper intends to compare and analyze the talent training models of the two representative tourism management schools in China and abroad including the Beijing Hospitality Institute and the Ecole Hoteliere de Lausanne (EHL) to sum up the experience of talent cultivation that China needs to learn from compared with foreign countries and something 
that other schools need to learn from compared with domestic excellent tourism colleges and universities. EHL is currently a very typical hotel management school in the world, and the Beijing Hospitality Institute is also one of the most distinctive hotel management schools in China. ${ }^{[3]}$ As typical representatives of tourism management schools at home and abroad, both of them have their own development paths and successful experiences. Among them, they have both common features and their own characteristics. This paper will compare and analyze their talent training models, draw the advantages of the two in the training of tourism talents and put forward the lessons for the training model of tourism talents in China's supply-side reform to improve the supply of tourism talents and promote the development of the tourism industry, and then promote the development of the "supply-side reform" strategy.

\section{Connection between supply-side reform and the training of tourism management tal- ents}

\subsection{Tourism education and supply-side reform supplement each other}

The education and economic development of tourism management schools exist two-way relations of mutual influence and interdependence. There is no fixed pattern in the education system of any country, and it must change with the economic system. The change of the economic system drives the speed of industrial transformation and the improvement of technical content, which is directly related to the quantity and quality of talent training of tourism management schools in China. So, China's economic situation will determine the content and the methods of China's tourism management talent training.

Supply-side reform is to promote structural reform from improving the quality of the supply side, and then to achieve effective expansion of the supply side. The development of tourism constantly promotes the progress of social economy and also drives the development of society, therefor, the effective supply of tourism management talents is one of the key forces to help the breakthrough and progress of China's tourism industry. ${ }^{[4]}$

The key to exploring the optimal model of talent training in tourism management schools in China is to discuss how to improve the quality of tourism manage- ment talent training and how to achieve effective supply. The quality of talent supply shall be improved from the perspective of the supply side and the promotion and reform of the supply structure of tourism management talent training. Therefore, the optimization of the tourism management talent training model is consistent with China's supply-side reform strategy, and the two complement each other.

\section{Taking EHL and Beijing Hospitality Insti- tute as an example to analyze the similarities and differences of talent training models be- tween tourism schools home and abroad}

EHL has a relatively complete hotel management education system. The connotation of disciplines and the diversification of majors have made the talent training model of EHL gradually mature and the "EHL model" has gradually become a model for tourism management schools.

Beijing Hospitality Institute mainly wants to train more and better hotel management talents for the capital and China's tourism industry. Since its establishment, it has always adhered to the international and applied school philosophy, focusing on the cultivation of students' professional abilities. When the school was first established, the school introduced the talent training model of EHL.

\subsection{Teachers}

Most of the teachers of EHL have experience in hotel industry, and are even part-time teachers in the hotel, which has played a positive role to allow the students of EHL to have professional knowledge and real-time information on the status of the hotel industry. EHL encourages and requires teachers to work part-time in enterprises in addition to teaching in EHL. ${ }^{[5]}$ Allowing teachers to work part-time in the hotel can continuously increase practical experience, which is of great significance to the teaching knowledge of teachers. According to the needs of the industry, teaching is always in line with the industry, ensuring that the courses arranged by the school and the knowledge taught by the teachers are in the forefront of the hotel industry. EHL also conducts regular and unscheduled assessments of teachers, requiring teachers to have teaching and research results that are in line with the actual situation, and must be innovative within a few years. If the assessment fails, it will be difficult for the teachers to continue to be hired. 
The teachers of Beijing Hospitali ty Institute is slightly weaker. Most teachers have graduated from colleges and universities, some teachers have overseas study experience and have received relevant professional training, and some teachers have hotel experience.

Compared with the requirement that foreign colleges require and encourage teachers to work in enterprises, schools in China do not support teachers to work part-time in hotels at present. In contrast, hotel management teachers in China lack the actual work experience of working in the hotel industry and real-time information is also slightly behind, most of the information comes from the Internet, lacking first-hand information. ${ }^{[6]}$

\subsection{Teaching methods}

EHL has been innovating the talent training model, and has focused on the needs of enterprises, attached importance to the combination of practice and theory, and implemented a cooperative model of combining industry, education and research. In the teaching process, the college is student-centered. In addition to the traditional lecture methods, teachers will also expand according to real-time hot issues. Through laboratory operations, case analysis, and students' own research and thinking, students' independent thinking ability, teamwork ability and communication ability have been trained.

During the teaching process, Beijing Hospitality Institute will also adopt interactive teaching methods, but the overall teaching method is basically based on teacher teaching and supplemented by student learning. During the teaching process, most of the questions are asked by teachers and answered by students.

\subsection{Curriculum structure}

The curriculum system grading of EHL is more obvious. For example, there are one or two basic courses, a few professional courses, and one or two management courses such as leadership science. The overall class hours are much less than those in China. Some courses rely entirely on students' self-study; the curriculum system setting of Beijing Hospitality Institute is more detailed, relatively speaking, there are more basic courses and theory courses, and less courses for completely independent study.

\section{Practical teaching}

There are six weeks of practical operation time after admission in EHL, which is called the "preliminary year". In this year, the students will be required to develop the basic operation ability of working in the guest room, catering and other departments. In addition to the teaching of theoretical knowledge, EHL also has practical courses with practical meanings such as practice classes and survey classes. After the end of each course, EHL will require students to carry out simulation operations for a period of time to fully apply theoretical knowledge to practice, understand and absorb the practical significance of theoretical knowledge. In addition, EHL will arrange students to have a paid internship in the hotel for half a year according to their arrangement. There is also a training hotel in the school, students can take turns to serve as guests and service staff, and teachers also give corresponding guidance.

During the teaching process, Beijing Hospitality Institute also follows the principle of attaching importance to theory and practice. During the academic year, students will be arranged to participate in simulated service operation skills, and corresponding paid internships will be arranged in the third and sixth semesters to consolidate students' understanding, absorption and application of theoretical knowledge. One of the teaching features of Beijing Hospitality Institute is the establishment of an independent teaching hotel for practical teaching with the Chinese restaurants, western restaurants, guest rooms, banquet halls, wine and cigar bars, bars, demonstration kitchens, coffee laboratories, wine tasting classrooms where the operation and teaching are perfectly combined according to hotel standards. Teaching is mainly concentrated in the first academic year, and the teaching hotel in the school is open to the outside, which has greatly strengthened the students' practical operation ability, not only let students be service staff, but also let students calculate operating costs and the overall planning of relevant departments and other practices, with a certain talent training characteristics.

\section{Talent training model of EHL for China to learn from}

By comparing the talent training models of the two representative tourism management schools, it can be seen that tourism management as an applied discipline, whether abroad or domestic, attaches great importance to the spiral development of theory and practice. The 
abroad talent training model represented by the EHL is worthy of our study. Of course, the talent training model of the Beijing Hospitality Institute is also useful for other tourism management schools in China.

\subsection{Cultivate students' professional awareness}

During the "preliminary year" of EHL at the beginning of its admission, in addition to cultivating students' abilities, it also pays more attention to cultivating students' professionalism. In the case of expanding students' horizons and achieving a win-win situation for the school and enterprise, the school cultivates students' professionalism and professional awareness in the teaching process and makes students to have a correct awareness of their own occupations and to avoid students' cognitive deviations in the service industry or even lose confidence in the hotel industry after the internship.

\subsection{Optimize school-enterprise cooperation}

The talent training model of EHL adopts the "order form", which can cultivate students' practical ability in a more targeted way, better combine theory and practice, and jointly develop relevant talent training programs by enterprises and schools so that students can be trained in a targeted way according to the corresponding positions and the school can build and renovate their teacher resources. Finally, in this way, more and better high-quality tourism management talents can be cultivated through the educational resources of both schools and enterprises. ${ }^{[7]}$ However, it should be noted that in this process, both schools and enterprises need to agree on relevant talent training programs and do a good job in the psychological work of students. School-enterprise cooperation requires joint attention and efforts by both parties.

\subsection{Strengthen the teacher resources}

In terms of teachers, the tourism education in China also needs to pay more attention to teachers' professional experience and support and encourage teachers to achieve the transformation of industries and schools. Teachers are one of the key factors in the process of talent training, because teachers' experience will influence students' cognition and judgment of the industry in the process of teaching. Therefore, China's tourism management schools should enable teachers to improve their abilities by participating in relevant training and communication and by taking part-time jobs in enterprises, and further increase the proportion of part-time teachers to gradually build a more profes- sional team of teachers, which not only enriches teachers' experience and practical experience, but also broadens students' knowledge dimension. ${ }^{[8]}$

\subsection{Increase the practical assessment of the course}

EHL will infiltrate practice into every type of discipline, and every time students complete a type of discipline, they will be required to simulate the relevant course content, while the Beijing Hospitality Institute only has classes combining theory and practice in the first academic year. Tourism management schools in China need to strengthen the assessment of the practice of professional disciplines to ensure that students can master the theoretical knowledge, consolidate and strengthen their actual operational ability through practice. The test of students' actual operational ability can not only train students' presentation ability and language expression ability, also test the students' mastery of knowledge. As we all know, it is far more effective for students to summarize knowledge and find problems by themselves than teachers instilling knowledge directly to them.

reference:

[1] Jie Zhang, Zijiang Li. Training System of Innovative and Entrepreneurial Talents Based on University-Enterprise Collaboration[J]. International Journal of Education and Economics,2019,2(4).

[2] Chen Yong, Della, damie. Overview of hotel and Tourism Management Education in Switzerland: citing the education experience of the Lausanne School of hotel management [J]. Journal of tourism, 2015,30(10):5-9

[3] Zhang Jiahui. Research on talent training of Tourism Management Major in Colleges and Universities under the supply side Reform [J]. Journal of Harbin vocational and technical college, 2019(06):54-57.

[4] Tourism Management Education in a multidimensional perspective [D]. Liaoning Normal University,2017.

[5] Nanmin. On tourism talents and Tourism Management Undergraduate Education [J]. Tourism overview (second half of the month), 2014(02):292-293.

[6] Xu Changgui. Countermeasures for employment promotion of tourism major in local colleges and Universities under the background of supply side Reform [J]. Century bridge, 2019(10):82-84

[7] Jiyuanyuan. Personnel training mode and experience reference of Lausanne Hotel Management College [J].Journal of Jincheng vocational and technical college, 2019,12 (05): 24-27.

[8] Lu junyang. Analysis of the characteristics of Applied Talents in Tourism Management Major -- Enlightenment from the Hotel Management Institute of Lausanne, Switzerland [J]. China management informatization, 2016,19(03):254-256. 